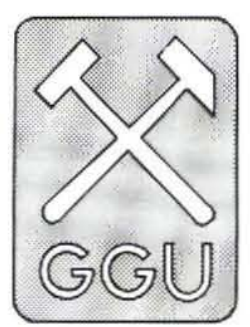

Investigations of Greenland's glaciers undertaken by GGU are primarily related to the exploitation of meltwater from the Inland Ice and local glaciers in western Greenland, i.e. they are essentially related to glacierhydrology (Olesen \& Braithwaite, 1989). The studies are therefore based on mass balance data combined with investigations of superglacial melt/refreezing and the determination of the internal mode of drainage. Related to this work is the documentation of short-term glacier changes at specific localities identified as being of special interest for hydropower from the point of view of glacier hazards, i.e. for example damage caused by tapping of ice dammed lakes or change of proglacial

\title{
Investigating Greenland's glaciers
}

\author{
Anker Weidick
}

draining caused by change in the glacier's thickness and extent. Similar documentation of long-term glacier fluctuations provides a background for control and modelling of past glacier fluctuations. The procedures have a direct bearing on the calculation of scenarios for future events related to the individual localities or, in a regional sense, to the impact of changes in Greenland glaciers on global sea level (the 'greenhouse effect').

\section{Glacier-hydrological work}

Collection of mass balance data in 1989 was continued in two areas around Buksefjorden $\left(64^{\circ} \mathrm{N}\right)$, at Ta-

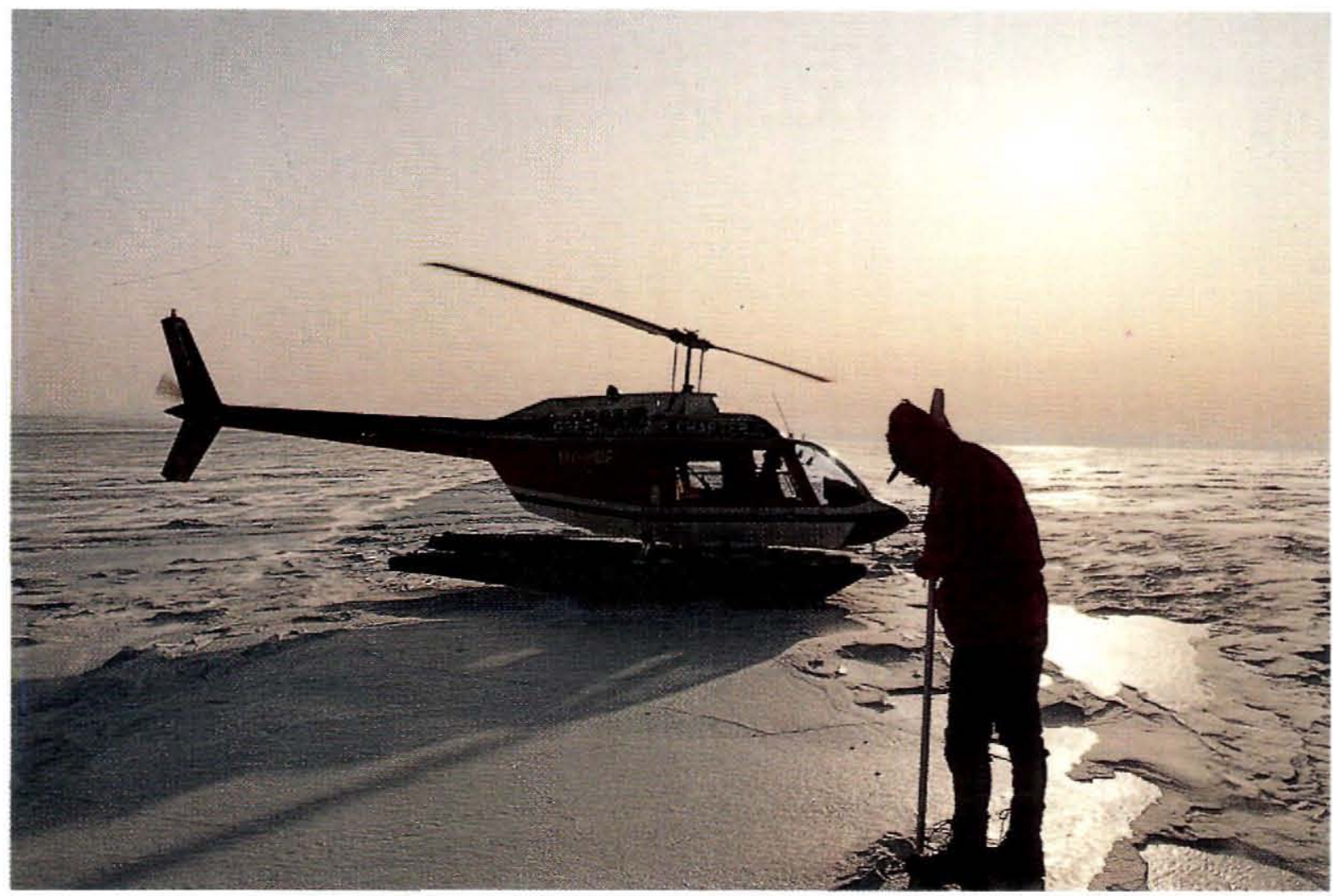

Studying the Greenland ice sheet to evaluate hydropower prospects. Stakes for measuring mass balance are driven into the ice surface near Pâkitsoq, central West Greenland, during a midnight helicopter visit in May. Photo: H. Højmark Thomsen. 


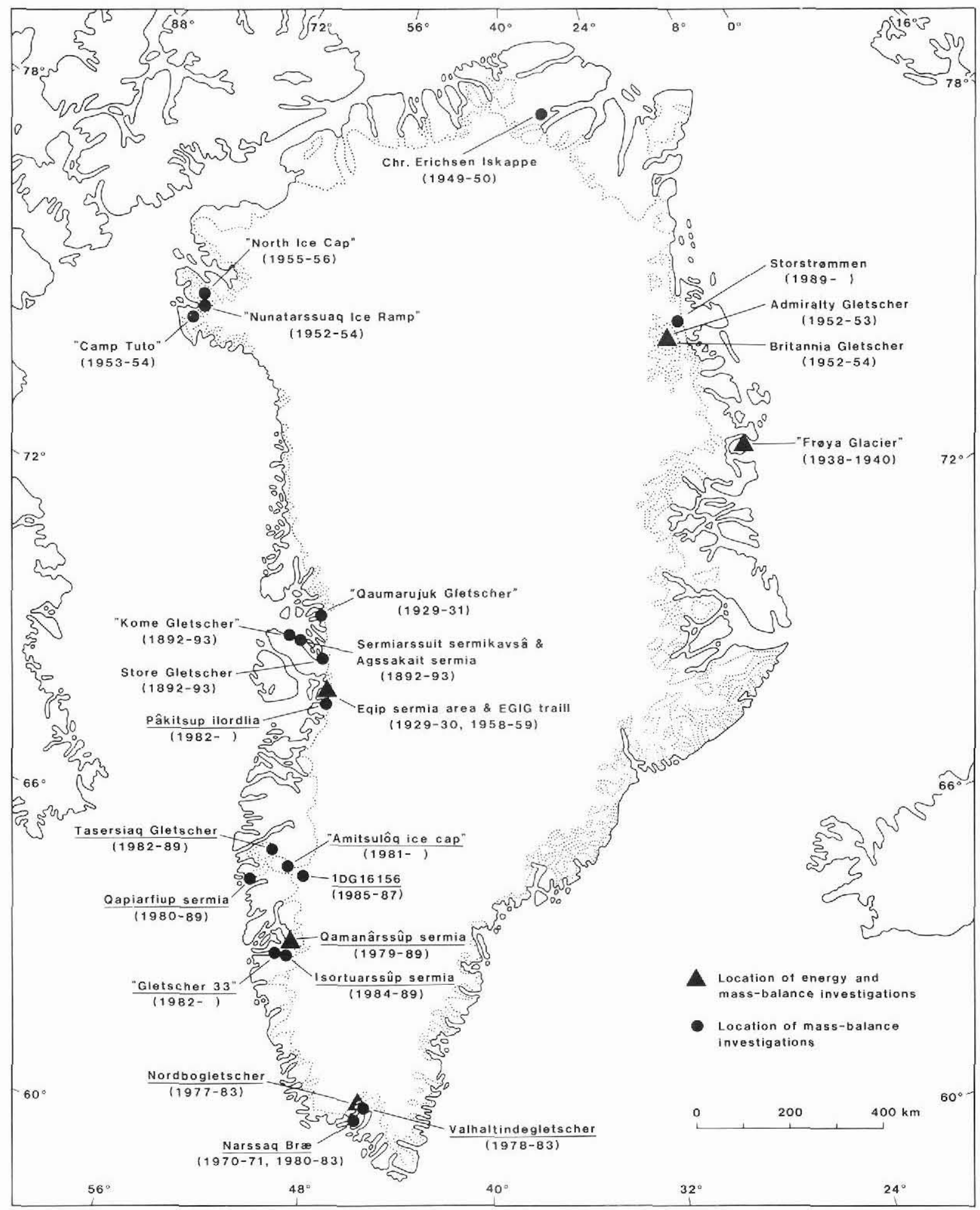

Fig. 1. Sketch map showing location of energy and mass-balance investigations at the margin of the Inland Ice and on local glaciers. Underlined: GGU activities. The years for study of the individual sites are given. Those still in operation are given by no terminal year for investigation. 


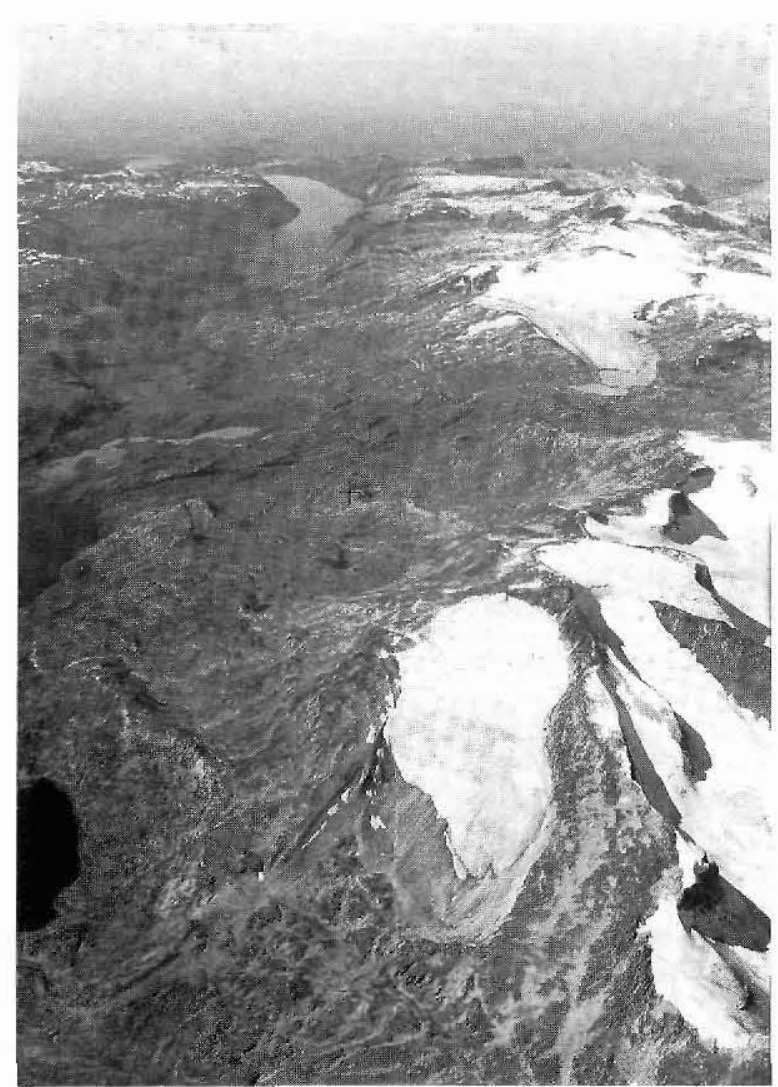

Fig. 2. Foreground: Glacier 1CG14033 ('Gletscher 33'). Background: Valley and head of Buksefjorden (Kangerdluarssúnguaq) where hydropower installations are planned to supply energy to Godthåb/Nuuk. The National Survey and Cadastre, Denmark, route 503 G-V no. 5021. Reproduced with permission A. 200/87.

sersiaq $\left(66^{\circ} \mathrm{N}\right)$, and at the locality of Pâkitsoq (Pâkitsup ilordlia) $\left(69^{\circ} 25^{\prime} \mathrm{N}\right)$. The localities of all reported mass and energy balance measurements in Greenland are shown in fig. 1 together with years of operation; those described in the following are underlined.

\section{Buksefjorden area}

In the Buksefjorden area, mass balance investigation on the Inland Ice at the two localities of Isortuarssûp sermia $\left(63^{\circ} 50^{\prime} \mathrm{N}\right)$ and Qamanârssûp sermia $\left(64^{\circ} 30^{\prime} \mathrm{N}\right)$ was brought to an end in 1989 . Continuous measurements have been carried out at Isortuarssûp sermia since 1984 and at Qamanârssûp sermia since 1979 (Braithwaite, 1989; Braithwaite \& Olesen 1989a), thus securing a solid data series for this part of the Inland Ice slope. The automatic climate recording station at Qamanârssûp sermia, driven in collaboration with Nuna-
Tek (a Home Rule technical organisation) and in operation since 1979 , will now be withdrawn.

Mass balance measurements were also carried out at a third locality in the area - the local cirque glacier 'Gletscher 33' in the Buksefjorden basin proper (fig. 2); they will be continued here due to the current interest in hydropower from the Buksefjorden area. This glacier has been the subject of measurements since 1982, and results of the investigations have been published by Braithwaite (1989).

\section{Tasersiaq area}

This area is related to the greatest hydropower potential in Greenland. Mass-balance measurements were carried out in 1989 at the localities of Qapiarfiup sermia, Tasersiaq Gletscher and 'Amitsulôq ice cap.' The series of mass-balance measurements at Qapiarfiup sermia and Tasersiaq Gletscher were brought to an end with the field work of 1989 , after continuous recording since 1980 and 1982 respectively.

On 'Amitsulôq ice cap' mass-balance measurements (Olesen, 1986) will be continued in connection with a specific investigation of refreezing processes in the firn areas of this ice cap. In connection with these investigations minor automatic climate stations, measuring only temperature and humidity, were operated during the summer of 1989.

\section{Pâkitsoq area}

Mass-balance measurements on the Inland Ice margin at Pâkitsoq have been undertaken since 1982, concentrating on the modelling of meltwater drainage in and under the ice (Braithwaite \& Thomsen, 1989; Thomsen et al., 1988). The studies include ice bore-holes in order to measure ice temperature and subglacial water pressure (Olesen, 1989). The selection of the site was based on existing detailed data on the surface and subsurface of the Inland Ice margin (Thomsen \& Olesen, 1990).

\section{Glaciological consequences of the 'greenhouse effect'}

Glacier run off studies were carried out to determine local variations in glacial contributions to hydropower (Braithwaite \& Olesen, 1988, 1989b). At the same time information on glacier ablation provides an important contribution to the global study of problems concerning glacier melt in connection with the 'greenhouse effect' and the consequent rise in sea level. This work is discussed further by Braithwaite (1990). 


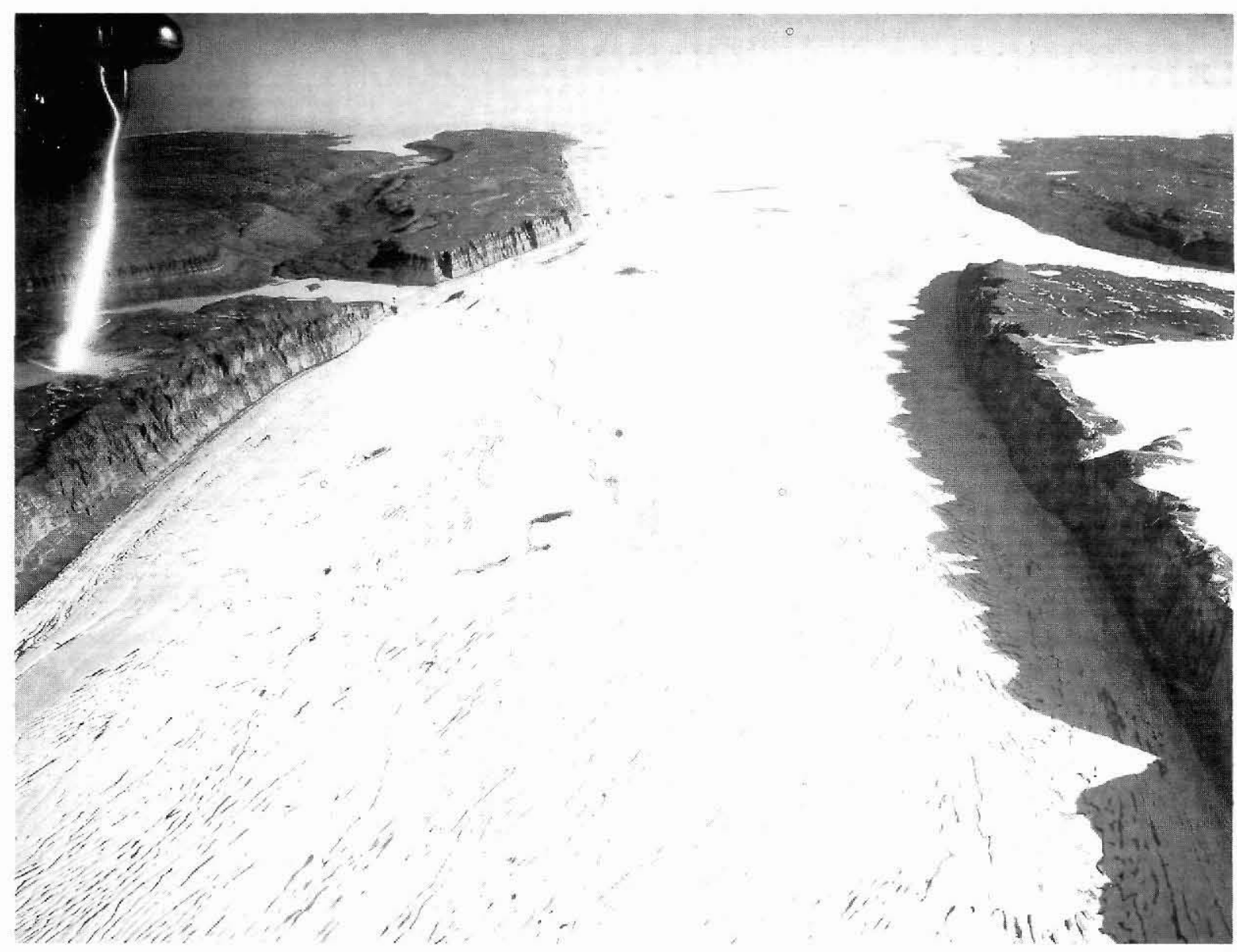

Fig. 3. Ryder Gletscher in North Greenland. This outlet from the Inland Ice has an average velocity at the front of $535 \mathrm{~m} \mathrm{a}^{-1}$ and is a possible source area for ice islands. The National Survey and Cadastre, Denmark, route 546 C-S no. 11015. Reproduced with permission A. 200/87.

\section{Calf ice production}

It is estimated that the annual loss from the Inland Ice by calf ice production is of the same order of magnitude as melting (i.e. $250-300 \mathrm{~km}^{3}$ water equivalent per year). However, the calculation of calf ice production (and its annual variations) is hampered by the lack of measurements on rate of movement of the glaciers producing calf ice.

Some rates of movement of calf ice producing outlets in North Greenland have been determined photogrammetrically (Higgins, 1988). However, only limited data are available on important glaciers from eastern and western Greenland and field measurements are lacking for most of the Inland Ice outlets, despite the growing interest in calf ice production as a hazard for offshore oil exploitation. The work on the outlet glaciers in North Greenland also points to these ice tongues as possible source areas for ice islands (fig. 3; Higgins, 1989).

\section{Glacier changes}

Monitoring of recent glacier fluctuations has been a special topic in those areas of special interest for hydropower. In other areas, glacier fluctuations have been documented in connection with geological mapping. Investigation of long-term fluctuation is focused on the magnitude of the retreat of the Inland Ice margin during the Holocene climatic optimum - nature's own experiment with the 'greenhouse effect'. Dating by ${ }^{14} \mathrm{C}$-accelerator of samples from the Pâkitsoq area and at the head of Godthåbsfjord has indicated a recession of the ice margin to a position some $10-20 \mathrm{~km}$ behind the present one about 5000 years ago. Studies of glacier changes are also carried out in collaboration with the Alfred Wegener Institute, West Germany, forming part of the field programme in Dronning Louise Land, North-East Greenland (see Henriksen, 1990). 


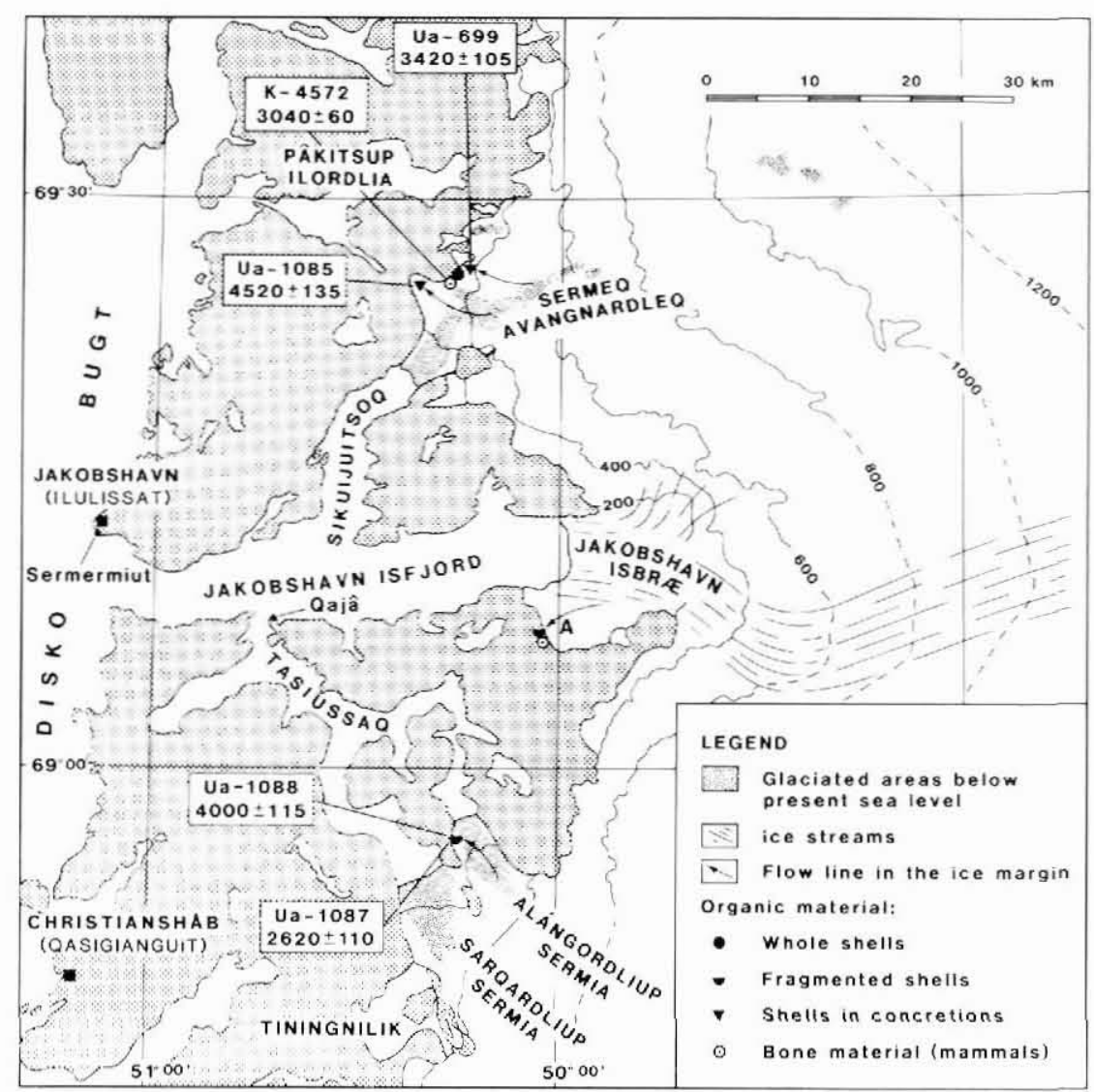

Fig. 4. Jakobshavn Isfjord and surroundings. The extension of subglacial fjords below the present ice margin is shown together with location of organic material brought to the present ice margin from the subglacial fjords. Laboratory number and ${ }^{14} \mathrm{C}$-age B.P. of samples are indicated. The trend of the subglacial fjord under Jakobshavn Isbræ is only indicated by the course of the ice stream due to lack of soundings.

\section{Mono-pulse radar measurements in the Jakobshavn area}

In connection with the investigation of glacier-hydrology and glacier changes in Jakobshavn, West Greenland, mono-pulse radar determination of the thickness of the Inland Ice margin was performed at 'Ice Bay' and at Pâkitsoq in 1989.

'Ice Bay' is an ice-filled embayment situated at the southern side of the front of Jakobshavn Isbræ (A in fig. 4) where the glacier ice forms an even plate, isolated from the fast moving central parts of the ice stream by a southern lateral shear zone. It is believed to be a relic from an earlier greater extent of the glacier. The preliminary interpretation of the soundings indicates a uniform ice thickness of about $200 \mathrm{~m}$ (Thorning, 1989).

Radar measurements in the Pâkitsoq area determined the thickness of a part of the ice margin, adjacent to a lake at $326 \mathrm{~m}$ a.s.l. and constituting a part of the lake complex of the Pâkitsoq hydropower scheme. The measurements performed in 1989 are supplementary to those obtained earlier by airborne radar mapping of the ice margin subsurface (Thomsen et al., 1988). These, together with mono-pulse radar measurements in the same area from 1988 (Thorning \& Hansen, 1989), will furnish details of the subsurface for an improved determination of the internal meltwater drainage of the ice margin.

\section{References}

Braithwaite, R. J. 1989: Glaciers and hydropower for Nuuk/ Godthăb, West Greenland. Open File Ser. Grønlands geol. Unders. 89/2, $49 \mathrm{pp}$.

Braithwaite, R. J. 1990: Effects of glaciers on annual runoff south of Nuuk/Godthåb, West Greenland. Rapp. Gronlands geol. Unders. 148 (this volume).

Braithwaite, R. J. \& Olesen, O. B. 1988: Winter accumulation reduces summer ablation on Nordbogletscher, South Greenland. Z. Gletscherk. Glazialgeol. 24, 21-30.

Braithwaite, R. J. \& Olesen, O. B. 1989a: Detection of climate signal by inter-stake correlations of annual ablation data, Qamanârssûp sermia, West Greenland. J. Glaciol. 35, 253259.

Braithwaite, R. J. \& Olesen, O. B. 1989b: Calculation of glacier ablation from air temperature, West Greenland. In Oerlemans, J. (edit.) Glacier fluctuations and climatic change, 219-233. Dordrecht: Kluwer Academic Publishers. 
Braithwaite, R. J. \& Thomsen, H. H. 1989: Simulation of run-off from the Greenland ice sheet for planning hydroelectric power, Jakobshavn/Ilulissat, West Greenland. Ann. Glaciol. 13, 12-15.

Henriksen, N. 1990: Regional geology and 1:500 000 mapping in North-East Greenland. Rapp. Grønlands geol. Unders. 148 (this volume).

Higgins, A. K. 1988: Glacier velocities from aerial photographs in North and North-East Greenland. Rapp. Grønlands geol. Unders. 140, 102-105.

Higgins, A. K. 1989: North Greenland ice islands. Polar Record 25(154), 207-212.

Olesen, O. B. 1986: Fourth year of glaciological field work at Tasersiaq and Qapiarfiup sermia, West Greenland. Rapp. Grønlands geol. Unders. 130, 121-126.

Olesen, O. B. 1989: A Danish contribution to the family of hot-water glacier drills, In Ice core drilling. Proceedings of the Third International Workshop on Ice Drilling Technology, Grenoble, France, Oct. 1988, 140-148.

Olesen, O. B. \& Braithwaite, R. J. 1989: Field stations for glacier-climate research, West Greenland. In Oerlemans, J. (edit.) Glacier fluctuations and climatic change, 207-218. Dordrecht: Kluwer Academic Publishers.

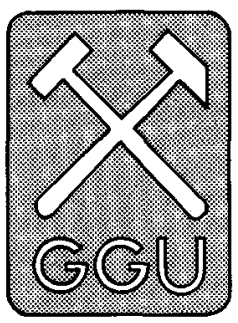

Glacier studies have been made in Greenland since the 1970s to plan hydro-electric power. However, there is also public concern about the extra melting from the Greenland ice sheet and local glaciers that may occur under a warmer climate due to the 'greenhouse effect' (Fenger \& Laut, 1989). The increase in melting will cause a rapid retreat of glaciers over the next 100 years and could give serious problems for large hydro-electric power stations. More seriously, glacier retreat in Greenland will also cause a rise in world sea level. Greenland is therefore a possible hazard to all low-lying land, including Denmark!

The amount of future sea level rise due to thermal expansion of sea water, melting of local glaciers, and changes in the ice sheets of Greenland and the Antarctic is still debated (National Research Council, 1985; Hekstra, 1986; Robin, 1986). It is hoped that an authoritative
Thomsen, H. H. \& Olesen, O. B. 1990: Continued glaciological investigations with respect to hydropower and ice-climate relationships, at Pakitsoq, Jakobshavn, West Greenland. Rapp. Grønlands geol. Unders. 148 (this volume).

Thomsen, H. H., Thorning, L. \& Braithwaite, R. J. 1988: Glacier-hydrological conditions on the Inland Ice north-east of Jakobshavn/Ilulissat, West Greenland. Rapp. Gronlands geol. Unders. 138, map sheet.

Thomsen, H. H., Thorning, L. \& Olesen, O. B. 1989: Applied glacier research for planning hydro-electric power, Jakobshavn/llulissat, West Greenland. Ann. Glaciol. 13, 257-261.

Thorning, L. 1989: Preliminary report of mono-pulse radar determinations of ice thicknesses at two localities near Ilulissat Glacier to lake 326, Pâkitsoq and the 'Ice Bay' south of Jakobshavn Isbræ. Unpubl. intern. GGU rep., 9 pp.

Thorning, L. \& Hansen, E. 1989: Measurements of ice thickness on glaciers at Isortuarssûp tasia, southern West Greenland and Pâkitsoq, central West Greenland. Rapp. Grønlands geol. Unders. 145, 59-63.

\section{A. W., Geological Survey of Greenland, Copenhagen.}

\section{Greenland glaciers and the 'greenhouse effect'}

\author{
Roger J. Braithwaite
}

assessment will be made in late 1990 by a working group of the Intergovernmental Panel on Climate Change which is chaired by J. Oerlemans (University of Utrecht, The Netherlands) and R. A. Warrick (University of East Anglia, UK) with participation of the present author. To anticipate the findings of this body, it can be said that a sea level rise of under a metre may occur in the next 100 years. Such assessments are good enough to show the potential threat of sea level rise but a precise forecast needs much more data. In particular, a better figure for Greenland's share of sea level rise can only be reached by more research in Greenland. GGU is encouraging this aim by helping foreign groups to plan projects and by its own research using the large amounts of data which have been collected to plan hydro-electric power. 